\title{
Minimally Modified Low Density Lipoprotein-induced Inflammatory Responses in Endothelial Cells Are Mediated by Cyclic Adenosine Monophosphate
}

\author{
Farhad Parhami, ${ }^{\star}$ Zhuang T. Fang, ${ }^{\star}$ Alan M. Fogelman, ${ }^{\star}$ Ali Andalibi, ${ }^{\star}$ Mary C. Territo, ${ }^{\star}$ and Judith A. Berliner ${ }^{\star *}$ \\ Departments of * Pathology and ${ }^{\ddagger}$ Medicine, University of California School of Medicine, Los Angeles, $90024-1732$
}

\begin{abstract}
We have previously shown that minimally oxidized LDL (MM-LDL) activated endothelial cells to increase their interaction with monocytes but not neutrophils, inducing monocyte but not neutrophil binding and synthesis of monocyte chemotactic protein-1 and monocyte colony-stimulating factor (MCSF). In the present studies we have examined the signaling pathways by which this monocyte-specific response is induced. Both induction of monocyte binding and mRNA levels for $M$ CSF by MM-LDL were not inhibited in protein kinase $C$-depleted endothelial cells. A number of our studies indicate that cAMP is the second messenger for the effects of MM-LDL cited above. Incubation of endothelial cells with MM-LDL caused a 173\% increase in intracellular cAMP levels. Agents which increased cAMP levels, including cholera toxin, pertussis toxin, dibutyryl cAMP, and isoproterenol mimicked the actions of MM-LDL. Agents which elevated cAMP were also shown to activate $\mathrm{NF}_{k B}$, suggesting a role for this transcription factor in activation of monocyte-endothelial interactions. Although endothelial leukocyte adhesion molecule (ELAM) mRNA synthesis can be regulated by NFkB, ELAM was not expressed and ELAM mRNA was only slightly elevated in response to MM-LDL. We present evidence that induction of neutrophil binding by LPS is actually suppressed by agents that elevated cAMP levels. (J. Clin. Invest. 1993. 92:471478.) Key words: atherosclerosis $\bullet M M-L D L \cdot c A M P \bullet$ inflammation • monocyte binding
\end{abstract}

\section{Introduction}

Activation of endothelial cells to synthesize binding molecules and chemotactic factors has been shown to elicit increased interaction with leukocytes (1-3). An important early event in the initiation of atherosclerosis is the increased interaction of monocytes with endothelial cells lining the vessel wall (4). In animals fed a high cholesterol diet, monocytes have been shown to bind more avidly to the endothelium, transmigrate through endothelial cell junctions, and enter the intimal space where they mature and form macrophages (5). These macrophages accumulate lipids and contribute to the formation of the fatty streak.

Address reprint requests to Farhad Parhami, Department of Pathology, UCLA School of Medicine, Center for the Health Sciences, 10833 LeConte Avenue, Los Angeles, CA 90024-1732.

Received for publication 30 October 1992 and in revised form 19 February 1993.

J. Clin. Invest.

(c) The American Society for Clinical Investigation, Inc. 0021-9738/93/07/0471/08 \$2.00

Volume 92, July 1993, 471-478
Since oxidized lipids have been found in fatty streak lesions (6) and experiments with antioxidants have shown reduced lesion formation (7), it is likely that these lipids play an important role in atherogenesis. Our group has shown that treatment of endothelial cells with minimally oxidized (modified) LDL (MM-LDL) ${ }^{1}$ but not native LDL caused an increase in monocyte but not neutrophil binding and an increase in the production of monocyte chemotactic protein-1 (MCP-1) and monocyte colony-stimulating factor (M-CSF) $\mathrm{mRNA}$ and protein (8-10). However no neutrophil chemotactic factor could be detected (11). In vivo studies showed that injection of MMLDL but not highly oxidized LDL into mice induced increases in mRNA for MCP-1 and M-CSF (12). Increased levels of mRNA for MCP-1 and M-CSF have been found in human fatty streak lesions $(13,14)$. MCP-1 is a highly active monocyte chemotactic factor (15). Proliferation and survival of monocytes and macrophages in the lesion may be supported by the local production of M-CSF (14). Among the inflammatory mediators that have been tested, including LPS, thrombin, IL1, and TNF (16-19), MM-LDL is the only one shown to induce monocyte but not neutrophil interaction with the endothelium. Understanding of the signaling molecules involved in the actions of MM-LDL is important since they also may be involved in other chronic inflammatory processes in vivo, characterized predominantly by monocytic infiltration.

To elucidate the mechanism of action of MM-LDL, we explored the signaling pathways by which it activates the endothelium. Two major second messengers that have been extensively studied are protein kinase C (PKC) and cAMP. The activation of both pathways in whole cells is mainly receptor mediated $(20,21)$. PKC is a family of closely related proteins that differ in substrate specificity, co-factor dependency, and tissue distribution (21). It exists in an inactive form in the cytoplasm of cells and is generally activated in the presence of calcium and diacylglycerol. Phorbol esters such as phorbol myristate acetate (PMA) are known to induce cellular responses by directly activating PKC (21). Agonist-induced cellular responses caused by PKC activation are down-regulated by pretreatment of cells with phorbol esters for 24-48 h (21). Regulation of the activity of adenylate cyclase and/or cAMP phosphodiesterase determines the levels of intracellular cAMP (20) and, consequently, the activity of cAMP-dependent protein kinase (PKA) (22). The activity of adenylate cyclase is

1. Abbreviations used in this paper: CS, calf serum; CT, cholera toxin; dbcAMP, dibutyryl cAMP; ELAM, endothelial leukocyte adhesion molecule; $G_{i}$, inhibitory $G$ protein; $G_{s}$ excitatory $G$ protein; IBMX, 3-isobutyl-1-methylxanthine; IP, isoproterenol; LPC, lysophosphatidylcholine; MDA, malondialdehyde; MCP-1, monocyte chemotactic protein-1; M-CSF, monocyte colony-stimulating factor; MM-LDL, minimally modified LDL; PKA, cAMP-dependent protein kinase; PKC, protein kinase $C$; $P_{L A}$, phospholipase $A_{2} ; P T$, pertussis toxin; RAEC, rabbit aortic endothelial cells; SLO, soybean lipoxygenase. 
regulated by excitatory $\left(G_{s}\right)$ and inhibitory $\left(G_{i}\right) G$ proteins (20). The role of $G$ proteins in mediating cellular responses to stimulators has been extensively reviewed $(23,24)$. Cholera toxin (CT) activates $\mathrm{G}_{\mathrm{s}}$ by ADP-ribosylating its alpha subunit, thus inhibiting its GTPase activity (25). Pertussis toxin (PT) has been shown to inhibit $G_{i}$ by ADP-ribosylation and to potentiate the effect of the stimulatory arm of the adenylate cyclase system (25). Many physiological agonists act via cell surface receptors to alter adenylate cyclase activity; isoproterenol (IP), a beta adrenergic receptor agonist, has been shown to elevate cAMP levels in endothelial cells by activating $G_{s}(26)$. In addition, purified PKC and isolated preparations of adenylate cyclase have been shown to be activated by certain native and oxidized fatty acids as well as products of lipid peroxidation (27-29), which may be present in MM-LDL. Also it has been reported that alteration of membrane physical properties by changing its lipid composition affects adenylate cyclase activity (30).

Activation of $\mathrm{NF}_{\kappa} \mathrm{B}$ has been associated with gene expression in response to increased PKC or PKA activity $(31,32)$. This transcription factor exists as a cytosolic dimer bound to an inhibitory molecule, $I_{\kappa} B(33)$. Activation of NFkB leads to its dissociation from $I \kappa B$ and its translocation to the nucleus where it binds to sequence-specific regulatory regions of several genes. We examined the ability of MM-LDL to activate $N_{K} B$ which may be involved in transcriptional regulation of genes by MM-LDL.

\section{Methods}

Cell preparation. Rabbit aortic endothelial cells (RAEC) at passages 9-17 and human aortic endothelial cells (11) or human aortic valve cells (kindly provided by Dr. Thomas Drake, UCLA School of Medicine) at passages 4-7 were used. For these studies, human monocytes were obtained by a modification of the Recalde method as described previously (8). The human neutrophil cell line HL60 (American Type Culture Collection, Rockville, MD) was used as a source of neutrophillike cells.

Leukocyte adhesion assay. For adhesion studies, endothelial cells were cultured in gelatin-coated 48-well dishes, in DME containing 15\% calf serum (CS), $5 \mu \mathrm{g} / \mathrm{ml}$ endothelial cell growth supplement (ECGS), and $8 \mu \mathrm{g} / \mathrm{ml}$ heparin (Sigma Chemical Co., St. Louis, MO). When confluent monolayers were formed, medium was changed to DME containing $10 \% \mathrm{CS}$ without ECGS and heparin $24 \mathrm{~h}$ before the experiment. This medium was then removed and agonists added to cells in DME with 5\% CS. The gradual lowering of the serum concentration minimized the basal levels of leukocyte binding to the endothelial monolayer. The concentration of LPS in medium containing each agonist was $<50 \mathrm{pg} / \mathrm{ml}$ as determined by chromogenic assay. This level of LPS when present in LDL is $\sim 50$-fold less than required to induce monocyte binding (data not shown). After $4 \mathrm{~h}$ of incubation with agonists at $37^{\circ} \mathrm{C}$, the endothelial monolayer was rinsed twice with DME containing $5 \% \mathrm{CS}$ and leukocytes were added at $10^{5}$ cells per well. After 20 min incubation at $37^{\circ} \mathrm{C}$, the unbound leukocytes were removed and the cells were fixed with $1 \%$ glutaraldehyde in PBS. The number of bound leukocytes was determined by counting a minimum of six fields per well using light microscopy.

Lipoprotein preparation. LDL was isolated by density gradient centrifugation of serum and stored in phosphate-buffered $0.15 \mathrm{M} \mathrm{NaCl}$ containing $0.01 \%$ EDTA.

MM-LDL was made using a modification of the method by Sparrow et al. (34) using soybean lipoxygenase (SLO) and phospholipase $\mathrm{A}_{2}\left(\mathrm{PLA}_{2}\right)$ (Sigma Chemical Co.). SLO and PLA $\mathrm{A}_{2}$ were separately bound to $\mathrm{CNBr}$-activated sepharose beads (Pharmacia Inc., Piscataway, $\mathrm{NJ})$ in coupling buffer $\left(0.1 \mathrm{M} \mathrm{NaHCO}_{3}, 0.5 \mathrm{M} \mathrm{NaCl}, \mathrm{pH} 8.3\right)$. Approximately $1,700 \mathrm{U}$ of SLO and $4 \mathrm{U}$ of $\mathrm{PLA}_{2}$ were bound per $\mathrm{mg}$ of beads. LDL was used after dialysis against PBS to remove the EDTA. $0.5 \mathrm{mg}$ of LDL in $1 \mathrm{ml}$ of PBS was incubated at $4^{\circ} \mathrm{C}$ for $24 \mathrm{~h}$ with $20 \mathrm{U}$ of $\mathrm{PLA}_{2}, 5,000 \mathrm{U}$ of SLO, and $1 \mathrm{mM} \mathrm{CaCl}$ in $12 \times 75 \mathrm{~mm}$ sterile polypropylene snap cap tubes. After $24 \mathrm{~h}$, an additional 5,000 $\mathrm{U}$ of SLO was added and tubes were incubated another $24 \mathrm{~h}$ at $4^{\circ} \mathrm{C}$. Finally, the enzymes were removed by centrifugation, and butylated hydroxytoluene and EDTA were added at $100 \mu \mathrm{M}$ and $0.3 \mathrm{mM}$, respectively. Preparations of MM-LDL used for these studies contained between 20 and $50 \mathrm{pg}$ LPS $/ \mathrm{ml}$ of medium. This enzymatic modification of LDL has generated biologically active MM-LDL that has been stable for several months at $4^{\circ} \mathrm{C}$.

Iron-oxidized LDL $(12,35)$, copper-oxidized $\operatorname{LDL}(36,37)$, and malondialdehyde (MDA)-LDL (38) were made according to the previously published methods. LDL was minimally oxidized by iron and highly oxidized by copper, giving 2 and $10 \mathrm{nmol}$ of thiobarbituric acidreactive substances per $\mathrm{mg}$ of cholesterol after dialysis, respectively.

Northern analysis. Endothelial cells were incubated at $37^{\circ} \mathrm{C}$ for $4 \mathrm{~h}$ with or without agonist in DME containing 5\% CS. Total RNA was isolated from cells using guanidine thiocyanate/phenol method (39). $10 \mu \mathrm{g}$ of RNA was denatured at $65^{\circ} \mathrm{C}$ for $10 \mathrm{~min}$ in $2.2 \mathrm{M}$ formaldehyde and $50 \%$ deionized formamide and was electrophoresed through $1 \%$ agarose gel containing $2.2 \mathrm{M}$ formaldehyde. RNA was transblotted to a nylon membrane (Hybond-N; Amersham Corp., Arlington Heights, IL) and cross-linked by ultraviolet light. The blot was prehybridized at $65^{\circ} \mathrm{C}$ for $2 \mathrm{~h}$ in $0.15 \mathrm{M} \mathrm{Na}_{2} \mathrm{HPO}_{4}, 0.25 \mathrm{M} \mathrm{NaH}_{2} \mathrm{PO}_{4}, 1 \mathrm{mM}$ EDTA, 7\% SDS, and $1 \% \mathrm{BSA}, \mathrm{pH} 7.0$, and hybridized in the same buffer at $65^{\circ} \mathrm{C}$ overnight with ${ }^{32} \mathrm{P}$-labeled DNA probes for alpha tubulin, MCP-1 (9), M-CSF (10), or endothelial leukocyte adhesion molecule (ELAM) (kindly provided by Dr. Brian Seed, Harvard Medical School, Boston, MA ). After hybridization, the blot was washed twice at room temperature in $2 \times \mathrm{SSC} / 0.1 \% \mathrm{SDS}$, and twice at $65^{\circ} \mathrm{C}$ in $0.5 \times$ $\mathrm{SSC} / 0.1 \%$ SDS, for $20 \mathrm{~min}$ each, and exposed to $\mathrm{x}$-ray film at $-70^{\circ} \mathrm{C}$. The extent of induction was determined by densitometric scanning.

$c A M P$ measurement. For measuring cAMP levels, RAEC were cultured in $60-\mathrm{mm}$ dishes and the cells were pretreated for $10 \mathrm{~min}$ with 0.5 mM 3-isobutyl-1-methylxanthine (IBMX, Calbiochem Corp., La Jolla, CA), an inhibitor of cAMP phosphodiesterase, in DME containing 5\% CS. Agonists were then added and cells collected at several time points after being rinsed twice with PBS containing $4 \mathrm{mM}$ EDTA (also an inhibitor of cAMP phosphodiesterase) and scraped into the same buffer. The cell pellet after centrifugation was resuspended in $100 \mu \mathrm{l}$ of boiling water containing $4 \mathrm{mM}$ EDTA. The suspension was sonicated, heated $3 \mathrm{~min}$ in a boiling water bath, and microcentrifuged for $2 \mathrm{~min}$ at high speed to spin out the coagulated proteins. The supernatant was used to determine cAMP levels.

Electrophoretic mobility shift assay. RAEC were cultured in 100$\mathrm{mm}$ dishes. Approximately $10^{7}$ cells were used per condition. After treatment with agonist, the cells were rinsed twice with ice-cold PBS and scraped into ice-cold PBS. The pellet was frozen in a dry ice/ethanol bath and stored at $-70^{\circ} \mathrm{C}$. Nuclear extracts were prepared according to the method described by Osborn et al. (40).

Electrophoretic mobility shift assay was performed using $6 \%$ nondenaturing polyacrylamide gel according to the protocol provided in NFKB DNA binding protein detection system from Gibco-Bethesda Research Laboratories (Gaithersburg, MD). The double-stranded oligonucleotide supplied is a $\mathbf{4 0}$ mer containing a tandem repeat of the consensus sequence for NF $\kappa$ B DNA binding site, -GGGGACTTTCC-.

\section{Results}

To facilitate our studies, a new method of producing MM-LDL has been developed that is a modification of the procedure of Sparrow et al. (34) involving treatment of LDL with SLO and $\mathrm{PLA}_{2}$. This method has several advantages compared with our previous method of long-term storage at $4^{\circ} \mathrm{C}$. The new method takes several days as compared with 6-12 mo, and LDL from 20 consecutive donors treated in this manner yielded biologically active MM-LDL. This enzymatic modification produced 
a low level of oxidation of LDL resulting in only a two- to threefold increase in conjugated dienes, an increase similar to that seen after cold storage. Like LDL that was minimally oxidized by storage, LDL oxidized by lipoxygenase and PLA caused an induction of monocyte but not neutrophil binding to RAEC treated for $4 \mathrm{~h}$ (Fig. 1). In addition, such MM-LDL preparations induced the synthesis of mRNA for MCP-1 and M-CSF, whereas native LDL did not cause such induction (Fig. $2 A$ ).

Characterization of second messengers. We initially examined the role of PKC in mediating the effects of MM-LDL. It has been reported that chronic incubation of cells with phorbol esters depletes the cellular content of PKC $\alpha$ and $-\beta$, which have been shown to be the most prevalent forms in endothelial cells (41). Treatment of RAEC for $4 \mathrm{~h}$ with 10-40 nM PMA caused a strong induction of monocyte binding that was signifcantly down-regulated by a 48 -h pretreatment with $10 \mathrm{~nm}$ PMA (Fig. $3 A$ ). This pretreatment did not down-regulate the binding induced by MM-LDL (Fig. $3 A$ ) but markedly downregulated PKC activity in the pretreated cells (data not shown). Similarly, PMA pretreatment also did not inhibit the induction of mRNA levels for M-CSF by MM-LDL whereas induction by PMA was inhibited significantly (Fig. $3 \mathrm{~B}$ ). Although the MM-LDL-induced increase in M-CSF mRNA was

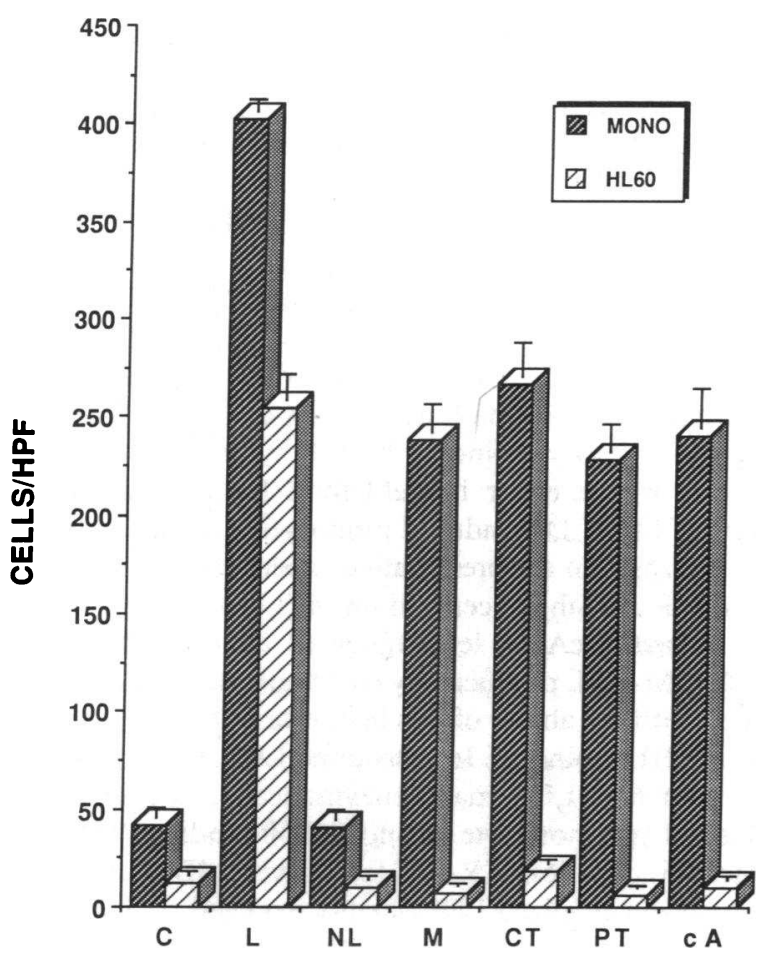

Figure 1. Induction of leukocyte binding to endothelial cells. RAEC were incubated for $4 \mathrm{~h}$ at $37^{\circ} \mathrm{C}$ with no additives $(C), \mathrm{LPS} 3 \mathrm{ng} / \mathrm{ml}$ $(L)$ as the positive control, native LDL $125 \mu \mathrm{g} / \mathrm{ml}(N L)$, MM-LDL $125 \mu \mathrm{g} / \mathrm{ml}(M)$, cholera toxin $400 \mathrm{ng} / \mathrm{ml}(C T)$, pertussis toxin 30 $\mathrm{ng} / \mathrm{ml}(P T)$, dbcAMP $1 \mathrm{mM}(c A)$. After incubation, leukocyte adhesion assay was performed using human monocytes or a neutrophillike cell line (HL60). The data are representative of three out of three experiments and the values from a representative experiment are reported as the mean number of monocytes bound per high power field $(\times 100) \pm \operatorname{SEM}(n=6)(p<0.001$ for C vs. M, C vs. CT, C vs. PT, and $\mathrm{C}$ vs. $\mathrm{cA}$ in the monocyte binding assay). $n=$ number of fields counted for each condition in the experiments.

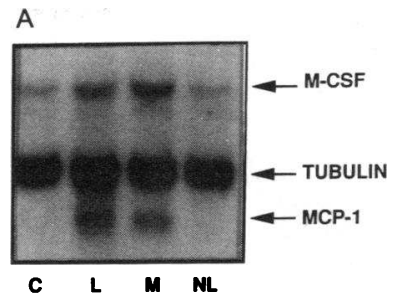

B

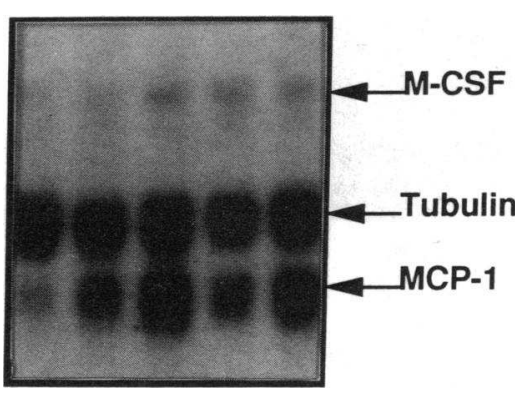

C L M CT M+CT

C

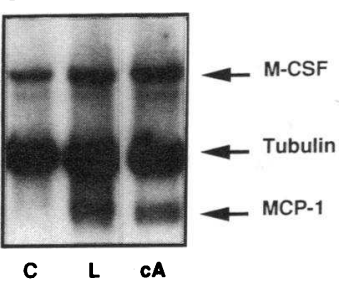

Figure 2. $(A, B, C)$ Induction of MCP-1 and M-CSF mRNA. RAEC were incubated at $37^{\circ} \mathrm{C}$ for $\mathbf{4} \mathrm{h}$ with no additives (C), LPS $3 \mathrm{ng} / \mathrm{ml}(L)$, MM-LDL $125 \mu \mathrm{g} / \mathrm{ml}$ $(M)$, native LDL 125 $\mu \mathrm{g} / \mathrm{ml}(N L)$, cholera toxin $400 \mathrm{ng} / \mathrm{ml}(C T)$, or dbcAMP $1 \mathrm{mM}(c A)$ alone or in combination in DME containing 5\% calf serum. Northern blot analysis was performed probing for MCP-1, M-CSF, and alpha tubulin. All Northern analyses were performed according to the previously reported methods $(9,10)$.

lower than that induced by PMA, similar findings were obtained in three out of three experiments. These results suggested that PKC is not the second messenger involved in mediating the induction of monocyte binding and increase of $\mathrm{M}$ CSF mRNA by MM-LDL.

We investigated the role of cAMP in the MM-LDL-induced cellular responses. Incubation of RAEC with MM-LDL resulted in a 40 and $173 \%$ elevation of intracellular cAMP levels after $10 \mathrm{~min}$ and $2 \mathrm{~h}$ of treatment, respectively. CT and PT both induced similar cellular responses as MM-LDL. Incubation of RAEC with CT for $2 \mathrm{~h}$ and with PT for $1 \mathrm{~h}$ increased cAMP levels 100 and $200 \%$, respectively (Table I). Both CT and PT treatment of RAEC for $4 \mathrm{~h}$ caused a concentration-dependent induction of monocyte but not HL60 binding, with maximum responses at $400 \mathrm{ng} / \mathrm{ml}$ of CT and $30 \mathrm{ng} / \mathrm{ml}$ of PT (Fig. 1). Both monocyte and HL60 binding were induced by LPS 10- and 20-fold, respectively (Fig. 1). There was no additive effect of CT + MM-LDL $(p=0.4579, n=6)$ or PT + MM-LDL $(p=0.3307, n=6)$ compared with each toxin alone, even though maximal monocyte binding had not been obtained (as seen in LPS-treated cells). This lack of additivity suggests that MM-LDL, CT, and PT may act via similar signaling pathways. The results from CT and PT studies strongly suggest the involvement of adenylate cyclase and intracellular cAMP levels in the specific induction of monocyte binding to endothelial cells.

Further evidence that increased cAMP levels are responsible for the effects of MM-LDL on induction of monocyte binding was suggested by the fact that pretreatment of cells with 0.2 mM IBMX, a cAMP phosphodiesterase inhibitor, for $10 \mathrm{~min}$ before MM-LDL treatment increased monocyte binding to 

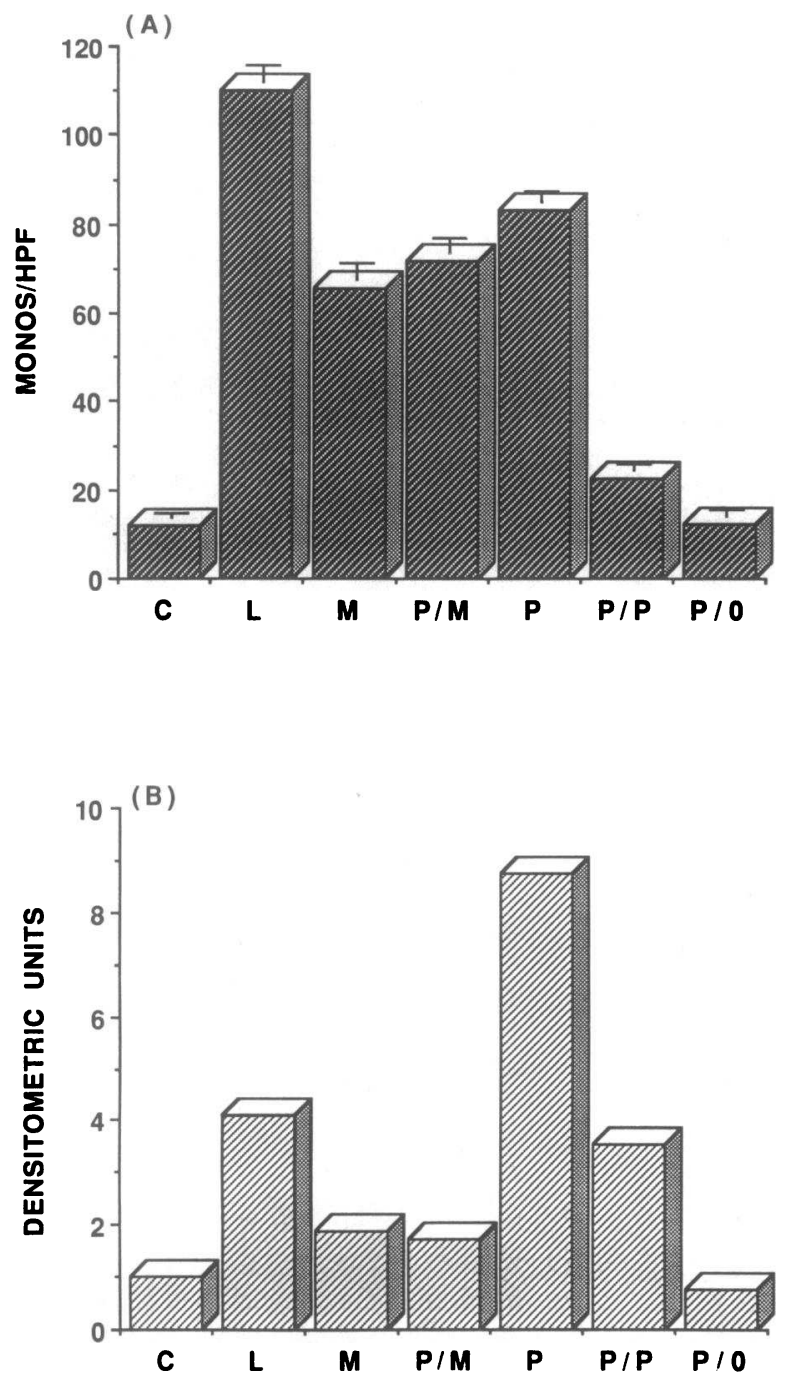

Figure 3. MM-LDL $(A)$ Induction of monocyte binding and $(B)$ induction of mRNA for M-CSF are not PKC mediated. ( $A$ ) RAEC were incubated at $37^{\circ} \mathrm{C}$ for $4 \mathrm{~h}$ with no additives $(C), \operatorname{LPS} 3 \mathrm{ng} / \mathrm{ml}$ $(L)$, MM-LDL $125 \mu \mathrm{g} / \mathrm{ml}(M)$, or PMA $40 \mathrm{nM}(P)$. In addition, to deplete the cellular content of PKC, cells were first pretreated with $10 \mathrm{nM}$ PMA in DME containing $10 \% \mathrm{CS}$ for $48 \mathrm{~h}$, indicated as $(P /)$, followed by 4-h treatment with a second agonist as described above. $\mathrm{P} / 0$ indicates $48 \mathrm{~h}$ pretreatment with $10 \mathrm{nM}$ PMA with no further treatments. After this incubation, monocyte adhesion assay was performed as described in the legend of Fig. 1. The data shown are representative of three out of three experiments and the values from a representative experiment are reported as the mean $\pm \operatorname{SEM}(n=6)$ $(p<0.001$ for $P$ vs. $P / P$, and $p=0.1985$ for $M$ vs. $P / M)$. ( $B)$ Northern blot analysis was performed, probing for M-CSF and alpha tubulin, using mRNA from cells treated similarly to those in $A$. The signals were traced, normalized to tubulin levels, and reported in densitometric units.

RAEC as compared with MM-LDL alone (MM-LDL $=76$, $\mathrm{IBMX}+\mathrm{MM}-\mathrm{LDL}=107, p<0.001, n=12)$. Also treating RAEC for $4 \mathrm{~h}$ with $1 \mathrm{mM}$ dbcAMP, which is known to be taken up by cells and leads to increased intracellular cAMP levels, induced monocyte binding sixfold but did not induce HL60 binding (Fig. 1). In addition, treating RAEC for $1 \mathrm{~h}$ with $5 \mu \mathrm{M}$ IP caused a $120 \%$ increase in cAMP level, and a threefold induction of monocyte binding ( $C=15$ vs. IP $=45, p<0.001$ in a representative of three experiments). HL60 binding was not
Table I. The Effect of Lipoproteins, CT, PT, and IP on cAMP Levels and Leukocyte Adhesion

\begin{tabular}{lccc}
\hline \multicolumn{1}{c}{ Agonist } & $\begin{array}{c}\text { Percent } \\
\text { change }\end{array}$ & $\begin{array}{c}\text { Monocyte binding } \\
\text { induced }\end{array}$ & $\begin{array}{c}\text { HL60 binding } \\
\text { induced }\end{array}$ \\
\hline MM-LDL & +173 & Yes & No \\
Iron-LDL & +122 & Yes & No \\
CT & +100 & Yes & No \\
PT & +200 & Yes & No \\
IP & +120 & Yes & No \\
Native LDL & -38 & No & No \\
MDA-LDL & -20 & No & No \\
Copper-LDL & -18 & No & No \\
LPC & -33 & No & No \\
& & & \\
\hline
\end{tabular}

RAEC were incubated at $37^{\circ} \mathrm{C}$ with $125 \mu \mathrm{g} / \mathrm{ml}$ MM-LDL $(M) 2 \mathrm{~h}$, $125 \mu \mathrm{g} / \mathrm{ml}$ iron-oxidized LDL $2 \mathrm{~h}, 400 \mathrm{ng} / \mathrm{ml}$ CT $2 \mathrm{~h}, 30 \mathrm{ng} / \mathrm{ml} \mathrm{PT} 1$ h, $5 \mu \mathrm{M}$ IP $1 \mathrm{~h}, 125 \mu \mathrm{g} / \mathrm{ml}$ native LDL $1 \mathrm{~h}, 125 \mu \mathrm{g} / \mathrm{ml}$ MDA-LDL $2 \mathrm{~h}, 125 \mu \mathrm{g} / \mathrm{ml}$ copper-oxidized LDL $2 \mathrm{~h}$, or $100 \mu \mathrm{M} \mathrm{LPC} 2 \mathrm{~h}$, in the presence of $0.2 \mathrm{mM}$ IBMX. cAMP levels were measured using an RIA kit (Amersham Corp.). The results of a representative experiment from three experiments reported as the mean of duplicate determinations with $<10 \%$ difference between the duplicates are shown as the percent change in cAMP levels compared with untreated cells $(+$ indicates an increase and - indicates a decrease in cAMP levels). Also reported is the ability of each agent to induce leukocyte binding after $4 \mathrm{~h}$ of treatment.

induced by IP. A shorter incubation period with IP was used because of the relatively transient elevation of cAMP by this agonist.

Since it is believed that increased intracellular cAMP effects are mediated by PKA (22), we tested the effect of $\mathrm{H}-8$, a PKA inhibitor, on the induction of monocyte binding by MM-LDL. Initially, several concentrations of H-8 within the range reported by other investigators were used to test for inhibition of CT induction of monocyte binding. $\mathrm{H}-8$ at $60 \mu \mathrm{M}$ inhibited induction of monocyte binding by CT by $50 \%$. RAEC pretreated with $\mathrm{H}-8$ at 60 or $100 \mu \mathrm{M}$ for $1 \mathrm{~h}$ demonstrated an inhibition of MM-LDL-induced monocyte binding of 50 and $70 \%$, respectively, in a representative experiment $(p<0.0001$ for $\mathrm{M}$ vs. $\mathrm{H}-8$ at both concentrations; $n=10$ ).

The increased cAMP level observed after incubation of cells with MM-LDL produced by enzymatic modification was associated with the ability of this lipoprotein to induce monocyte but not $\mathrm{HL} 60$ binding. Iron-oxidized LDL, which has similar effects to MM-LDL made enzymatically, also increased cAMP levels and monocyte but not HL60 binding (Table I). By contrast, incubation of RAEC for $2 \mathrm{~h}$ with MDA-LDL ( 125 $\mu \mathrm{g} / \mathrm{ml}$ ), copper-oxidized LDL (highly oxidized, $125 \mu \mathrm{g} / \mathrm{ml}$ ), or lysophosphatidylcholine (LPC, $100 \mu \mathrm{M}$ ) decreased cAMP levels and did not induce either monocyte or HL60 binding (Table I).

The possible involvement of cAMP elevation in the induction of mRNA for MCP-1 and M-CSF by MM-LDL was also tested. Like MM-LDL, CT treatment of endothelial cells increased message for both MCP-1 and M-CSF twenty- and fourfold, respectively (Fig. $2 \mathrm{~B}$ ), as determined by densitometric scanning. Incubation of RAEC with $1 \mathrm{mM}$ dbcAMP for $4 \mathrm{~h}$ also caused a 10-fold increase in MCP-1 and a 3-fold increase in M-CSF mRNA levels as determined by densitometric scanning (Fig. $2 C$ ). In addition, M-CSF mRNA level was elevated 
approximately twofold after $4 \mathrm{~h}$ of incubation with IP. Treatment of RAEC for $4 \mathrm{~h}$ with the agents that lowered cAMP, including LPC (shown in Table I), did not increase mRNA levels for M-CSF (data not shown).

$M M-L D L$ activates $N F_{\kappa} B$. Previous reports have shown that NFKB activation in cytosolic extracts is at least partly mediated by phosphorylation of the NFKB/I $\mathrm{KB}$ complex by PKA (31). The ability of MM-LDL to activate $N F \kappa B$ was assessed by incubating RAEC with MM-LDL for $2 \mathrm{~h}$ and testing for enhanced $N_{K} \mathrm{~B}$ binding to a labeled sequence-specific oligonucleotide in an electrophoretic mobility shift assay. As shown in Fig. $4 A$ there was significant activation of NF $\kappa$ B by LPS and MM-LDL, but not by native LDL. This experiment was performed with four different MM-LDL preparations, all of which gave similar results. CT treatment of RAEC for $2 \mathrm{~h}$ also caused activation of NF $\kappa$ B (Fig. $4 B$ ).

Why neutrophil binding is not increased by $M M-L D L$. ELAM is the major neutrophil-binding molecule on endothelial cell (42). Treatment of endothelial cells with MM-LDL did not increase surface expression of ELAM whereas LPS increased expression fourfold (Fig. $5 A$ ). MM-LDL in contrast to LPS caused only a minimal increase in ELAM mRNA levels, whereas both agents caused a major elevation of MCP-1 mRNA (Fig. $5 B$ ). We found that induction of neutrophil binding was actually inhibited by agents that elevate cAMP levels,

\section{A}

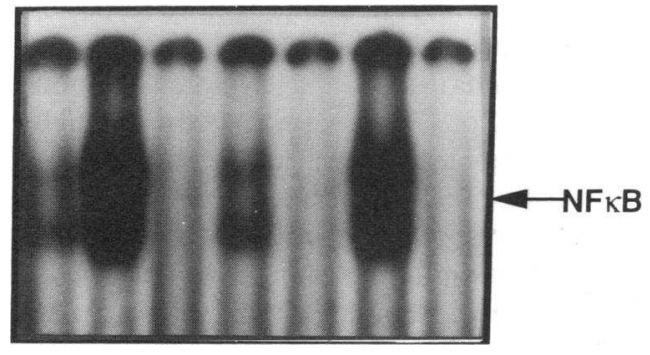

$\begin{array}{lllllll}\text { C } & M & M^{*} & \mathbf{N L} & \mathbf{N L}^{*} & \mathbf{L} & \mathbf{L}^{*}\end{array}$

B

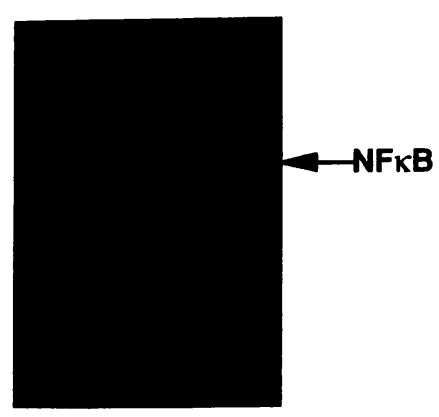

L $\quad C T \quad C \quad M$

Figure 4. NF $\kappa$ B activation by MM-LDL or CT. $(A)$ RAEC were treated for $2 \mathrm{~h}$ at $37^{\circ} \mathrm{C}$ with no additives $(C)$, MM-LDL $125 \mu \mathrm{g} / \mathrm{ml}$ $(M)$, native LDL $125 \mu \mathrm{g} / \mathrm{ml}(N L)$, or LPS $3 \mathrm{ng} / \mathrm{ml}(L)$. Electrophoretic mobility shift assay was performed using nuclear extracts of these cells following incubation with ${ }^{32} \mathrm{P}$-labeled sequence-specific oligonucleotide in the absence or presence $\left({ }^{*}\right)$ of unlabeled competitor oligonucleotide. $(B)$ RAEC were treated with LPS $(L)$, cholera toxin $(C T)$, no additives $(C)$, or MM-LDL $(M)$ under similar conditions as in $A$. All experiments on activation of NFKB were performed on cells that had been tested for responsiveness to the agents used in adhesion and mRNA studies.

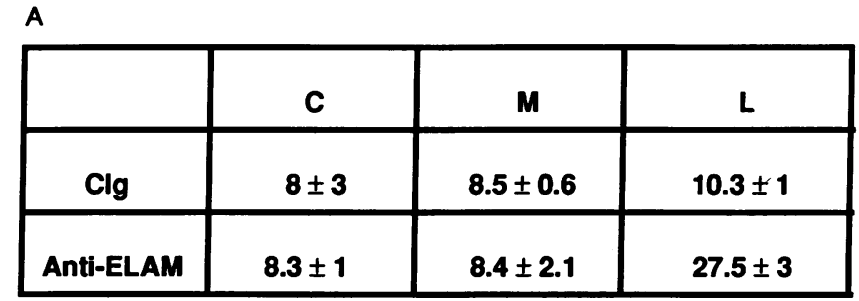

B

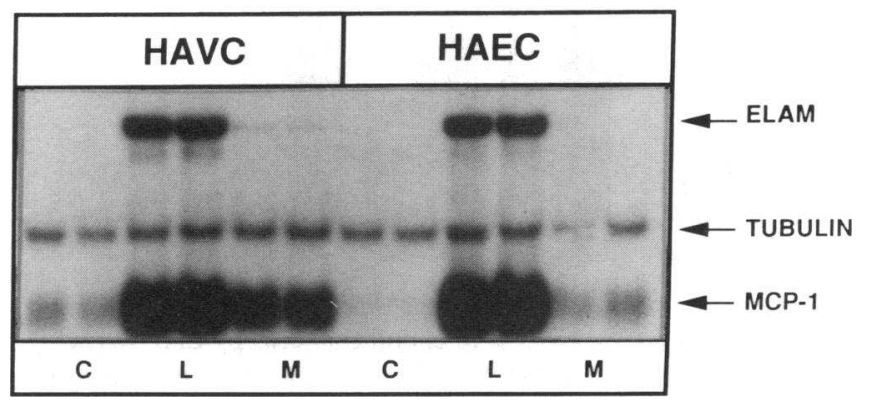

Figure 5. Induction of ELAM $(A)$ protein and (B) mRNA. $(A)$ ELISA assay of ELAM on cell surface was performed. Human aortic endothelial cells, cultured as previously described (9), were incubated with no additives $(C)$, MM-LDL $100 \mu \mathrm{g} / \mathrm{ml}(M)$, or LPS $1 \mathrm{ng} / \mathrm{ml}$ $(L)$ for $4 \mathrm{~h}$. Cells were then washed and exposed to control IgG ( CIg, anti-CD3) or anti-ELAM antibody P6E2 (kindly provided by Cytel Corporation, La Jolla, CA) for $1 \mathrm{~h}$, followed by peroxidase-labeled goat anti-mouse secondary antibody for $2 \mathrm{~h}$. P6E2, an Ig3, crossreacted with the ELAM-1 protein and immunoprecipitated with $\mathrm{H} 18 / 7$ (57). Values are reported as O.D. $\times 1,000 \pm \mathrm{SD}(n=4) .(B)$ Human aortic valve cells $(H A V C)$ or human aortic endothelial cells $(H A E C)$ were incubated for $4 \mathrm{~h}$ at $37^{\circ} \mathrm{C}$ with no additives $(C)$, LPS $(L)$, or MM-LDL $(M)$. Northern blot analysis was performed using RNA extracted from the cells and probed for MCP-1, ELAM, and alpha tubulin. All other conditions were similar to those described for other Northern blot analyses. Duplicate lanes are shown for each condition.

such as CT. Incubation of RAEC with $3 \mathrm{ng} / \mathrm{ml}$ LPS for $4 \mathrm{~h}$ increased HL60 and monocyte binding to endothelial cells 13and 9-fold, respectively (Fig. 6). Incubation of endothelial cells with $400 \mathrm{ng} / \mathrm{ml} \mathrm{CT}$ and $0.5 \mathrm{mM}$ IBMX for $2 \mathrm{~h}$ followed by $4 \mathrm{~h}$ of incubation with $3 \mathrm{ng} / \mathrm{ml}$ LPS significantly inhibited the induction of HL60 but not monocyte binding by LPS (Fig. 6). Such inhibition of the induction of HL60 and not monocyte binding by LPS was also seen after pretreatment of endothelial cells with MM-LDL (Fig. 6).

\section{Discussion}

Exposure of endothelial cells to MM-LDL leads to increased monocyte but not neutrophil binding (Fig. 1) and mRNA levels for MCP-1 and M-CSF (Fig. $2 A$ ). Since the pattern of leukocyte binding and mRNA induction by MM-LDL is distinct from that of other inflammatory agents, we suspected the signaling pathways might be different. A number of studies have concluded that PKC plays a role in the signal transduction pathways initiated by thrombin, TNF- $\alpha$, IL-1, and LPS (9, 16). PMA pretreatment of endothelial cells, which has been shown to deplete the cellular content of PKC (43), down-regulated the monocyte binding induced by PMA (Fig. $3 A$ ) but did not inhibit the MM-LDL-induced monocyte binding or the MM-LDL-mediated increase in M-CSF mRNA (Fig. $3 \mathrm{~B}$ ), supporting the conclusion that $\mathrm{PKC}$ is not involved in these 


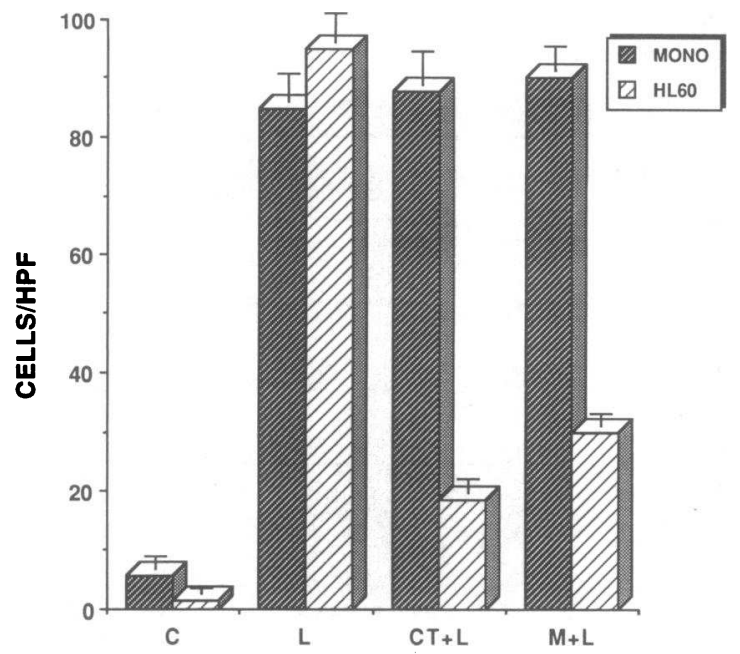

Figure 6. Effect of cholera toxin and MM-LDL on induction of neutrophil and monocyte binding to endothelial cells by LPS. RAEC were incubated for $2 \mathrm{~h}$ at $37^{\circ} \mathrm{C}$ with or without cholera toxin $(C T)$ $400 \mathrm{ng} / \mathrm{ml}$, or MM-LDL $125 \mu \mathrm{g} / \mathrm{ml}(M)$ in presence of $0.2 \mathrm{mM}$ IBMX, followed by $4 \mathrm{~h}$ incubation with no additives $(C)$ or LPS 1 $\mathrm{ng} / \mathrm{ml}(L)$. Leukocyte adhesion assay was performed using HL60 and monocytes. The data are representative of three out of three experiments and the values from a representative experiment are reported as the mean number of cells bound per high power field \pm SEM $(n=9)$.

cellular responses. Furthermore, it has been previously shown that, in fibroblasts, the increase of mRNA levels for JE, the murine homologue of MCP-1 gene (44), by MM-LDL is PKC independent.

Another second messenger that mediates agonist-induced cellular responses is CAMP. It has been reported that cAMP levels mediate endothelial barrier properties (45), as well as endothelium-dependent relaxations in response to thrombin, serotonin, and UK14304 (a selective $\alpha_{2}$-adrenergic receptor agonist ) (46). Of relevance to the present report is the observation by Sung et al. (26) that CT treatment of human umbilical vein endothelial cells induced adhesion of U937 monocytic cells to endothelial cells.

In this report we present data strongly suggesting that the effects of MM-LDL prepared by enzymatic modification or mild iron oxidation are mediated by cAMP. We have shown that incubation of endothelial cells with MM-LDL increased the levels of intracellular cAMP (Table I). The responses induced by CT and PT, both of which caused elevation of cAMP levels (Table I), and dbcAMP itself were similar to those induced by MM-LDL. These responses included increased monocyte but not HL60 binding (Fig. 1), and increased levels of mRNA for MCP-1 and M-CSF (Fig. 2). There was no additive effect of MM-LDL plus CT or PT, which suggests that these agents may act via the same mechanism as MM-LDL. Furthermore, IP elevated cAMP levels in endothelial cells, increased monocyte but not HL60 binding, and increased M-CSF mRNA level. Native LDL, MDA-LDL, highly oxidized LDL, and LPC did not increase cAMP levels and did not induce the cellular responses to MM-LDL reported in the present study.

The results of our studies give some insight into the possible mechanisms by which MM-LDL increases cAMP. The fact that both CT and PT mimic the effects of MM-LDL suggests that the regulation of CAMP concentration by MM-LDL may be at the level of $G_{3}$ or $G_{i}$ proteins. A significant level of $G_{i}$ has been detected in endothelial cells (47). The fact that in these cells PT increased cAMP levels suggests that perhaps under normal conditions an active population of $G_{i}$ proteins may regulate adenylate cyclase activity in aortic endothelial cells, as well as the expression of monocyte-binding molecules, MCP-1, and M-CSF. The inhibition of $G_{i}$ by PT would alleviate its negative effect, thus leading to an increase in cAMP levels.

We are currently in the process of characterizing the active lipid component(s) of MM-LDL. Our studies have shown that neutral lipids (including oxidized fatty acids) (8) and LPC (current study) are not responsible for the effects of MM-LDL on endothelial cells after $4 \mathrm{~h}$ of treatment. Our past and ongoing studies suggest that the active lipid responsible for the effects seen at $4 \mathrm{~h}$ is an oxidized phospholipid (8). Previous reports showed that treatment of RAEC with levels of LPC used by us caused only a modest (1.4-fold) increase in monocyte binding (compared with the 4-10-fold induction seen with MM-LDL) and that the major effect of LPC was seen after $24 \mathrm{~h}$ (48). Our previous studies have shown that effects of MMLDL may continue to act up to $48 \mathrm{~h} \mathrm{(8)}$, and it is clearly possible that different lipids, such as LPC, or lipoxygenase products, such as oxidized fatty acids, as reported by others to be active in monocytes (49), may be responsible for the prolonged activation.

Since an $\mathrm{NF}_{\kappa} \mathrm{B}$ binding site is present in the promoter region of JE (50) and M-CSF genes (50a), and cAMP has been suggested to play a role in $\mathrm{NF}_{K} \mathrm{~B}$ activation (51), we suspected that $\mathrm{NF} \kappa \mathrm{B}$ may also be associated with MM-LDL regulation of gene transcription. Our results indicate that treatment of endothelial cells with MM-LDL or CT causes activation of $\mathrm{NF} \kappa \mathrm{B}$, whereas native LDL does not lead to such activation (Fig. 4, $A$ and $B$ ). This suggests that NF $\kappa$ bactivation is associated with the induction of cellular responses to increased intracellular cAMP levels. Our investigations have shown, however, that not all genes with $\mathrm{NF}_{\kappa} \mathrm{B}$ binding site in their promoter region are induced by MM-LDL; mRNA levels of ELAM (52) were only minimally induced (Fig. $5 B$ ). We have further shown that increased cAMP levels induced by MM-LDL or CT inhibited the induction of neutrophil and not monocyte binding by LPS (Fig. 6). Similarly, dibutyryl cAMP and forskolin suppression of LPS-induced TNF- $\alpha$ gene expression has been previously reported (53). Pober et al. (54) reported that increased cAMP levels in forskolin-treated human umbilical vein endothelial cells inhibited TNF-induced ELAM expression. Our results also support the observation by Montgomery et al. (55) that $\mathrm{NF} \kappa \mathrm{B}$ is associated with but is not sufficient for ELAM message induction. We suggest that the MM-LDL-induced increase in cAMP levels inhibits ELAM expression.

It is evident from our observations that the increased monocyte binding induced by MM-LDL is independent of ELAM since MM-LDL did not increase ELAM expression (Fig. $5 \mathrm{~A}$ ). We have also ruled out VCAM and ICAM in contributing to the increased monocyte binding seen after $4 \mathrm{~h}$ incubation of endothelial cells with MM-LDL (56). We suggest that MMLDL up-regulates another monocyte binding molecule, the expression of which is mediated via a cAMP-dependent pathway. Further characterization of this binding molecule is the subject of separate studies.

We propose that cellular responses to MM-LDL and perhaps to other inducers of chronic inflammatory responses characterized by inducing monocyte but not neutrophil infil- 
tration are regulated by cAMP. In fatty streak lesions, MMLDL may induce monocyte infiltration by increasing cAMP. It is also possible that physiological agonists of beta adrenergic receptors (i.e., epinephrine and norepinephrine) may contribute to monocyte infiltration in atherogenesis and perhaps to other inflammatory processes. We propose that the second messenger, cAMP, activates $\mathrm{NF} \kappa \mathrm{B}$, and perhaps other transcription factors, and may inhibit transcription of genes such as ELAM, which would otherwise promote neutrophil binding.

\section{Acknowledgments}

This research was supported by National Institutes of Health grants HL-30568 and TRDRP RT372 and the Laubisch Fund.

\section{References}

1. Bevilacqua, M. P., J. S. Pober, M. E. Wheeler, R. S. Cotran, and M. A Gimbrone. 1985. Interleukin 1 acts on cultured human vascular endothelium to increase the adhesion of polymorphonuclear leukocytes, monocytes, and related leukocyte cell lines. J. Clin. Invest. 76:2003-2011.

2. Carlos, T. M., B. R. Schwartz, N. L. Kovach, E. Yee, M. Rosa, L. Osborn, G. Chi-Rosso, B. Newman, and R. Lobb. 1990. Vascular cell adhesion molecule1 mediates lymphocyte adherence to cytokine-activated cultured human endothelial cells. Blood. 76:965-970.

3. Rollins, B. J., T. Yoshimura, E. J. Leonard, and J. S. Pober. 1990. Cytokine-activated human endothelial cells synthesize and secrete a monocyte chemoattractant, MCP-1/JE. Am. J. Pathol. 136:1229-1233.

4. Ross, R. 1986. The pathogenesis of atherosclerosis-an update. N. Engl. J. Med. $314: 488-500$.

5. Gerrity, R. J., H. K. Naito, M. Richardson, and C. M. Schwartz. 1979. Dietary induced atherogenesis in the swine. Am. J. Pathol. 95:775-791.

6. Yla-Herttuala, S., W. Palinski, M. E. Rosenfeld, S. Parthasarathy, T. E. Carew, S. Butler, J. L. Witztum, and D. Steinberg. 1989. Evidence for the presence of oxidatively modified low density lipoprotein in atherosclerotic lesions of rabbit and man. J. Clin. Invest. 84:1086-1095.

7. Kita, T., Y. Nagano, M. Yokode, K. Ishii, N. Kume, A. Ooshima, H. Yoshida, and C. Kawai. 1987. Probucol prevents the progression of atherosclerosis in Watanabe heritable hyperlipidemic rabbit, an animal model for familial hypercholerterolemia. Proc. Natl. Acad. Sci. USA. 84:5928-5931.

8. Berliner, J. A., M. C. Territo, A. Sevanian, S. Ramin, J. A. Kim, B. Bamshad, M. Esterson, and A. M. Fogelman. 1990. Minimally modified low density lipoprotein stimulates monocyte endothelial interactions. J. Clin. Invest. $85: 1260-1266$

9. Cushing, S. D., J. A. Berliner, A. J. Valentine, M. C. Territo, M. Navab, F. Parhami, R. Gerrity, C. J. Schwartz, and A. M. Fogelman. 1990. Minimally modified low density lipoprotein induces monocyte chemotactic protein 1 in human endothelial cells and smooth muscle cells. Proc. Natl. Acad. Sci. USA. 87:5134-5138.

10. Rajavashisth, T. B., A. Andalibi, M. C. Territo, J. A. Berliner, M. Navab, A. M. Fogelman, and A. J. Lusis. 1990. Induction of endothelial cell expression of granulocyte and macrophage colony-stimulating factors by modified low-density lipoproteins. Nature (Lond.). 344:254-257.

11. Berliner, J. A., M. C. Territo, L. Almada, A. Carter, E. Shafonsky, and A. M. Fogelman. 1986. Monocyte chemotactic factor produced by large vessel endothelial cells in vitro. Arteriosclerosis. 6:254-258.

12. Liao, F., J. A. Berliner, M. Mehrabian, M. Navab, L. Demer, A. J. Lusis, and A. M. Fogelman. 1991. MM-LDL is biologically active in vivo in mice. $J$. Clin. Invest. 87:2253-2257.

13. Nelken, N. A., S. R. Coughlin, D. Gordon, and J. N. Wilcox. 1991. Monocyte chemoattractant protein-1 in human atheromatous plaques. J. Clin. Invest. 88:1121-1127.

14. Clinton, S. K., R. Underwood, L. Hayes, M. L. Sherman, D. W. Kufe, and P. Libby. 1992. Macrophage colony-stimulating factor gene expression in vascular cells and in experimental and human atherosclerosis. Am. J. Pathol. 140:301316.

15. Yla-Herttuala, S., B. A. Lipton, M. E. Rosenfeld, T. Sarkioja, T. Yoshimura, E. J. Leonard, J. L. Witztum, and D. Steinberg. 1991. Expression of monocyte chemoattractant protein 1 in macrophage-rich areas of human and rabbit atherosclerotic lesions. Proc. Natl. Acad. Sci. USA. 88:5252-5256.

16. Lane, T. A., G. E. Lamkin, and E. V. Wancewicz. 1990. Protein kinase C inhibitors block the enhanced expression of intercellular adhesion molecule-1 on endothelial cells activated by interleukin-1, lipopolysaccharide and tumor necrosis factor. Biochem. Biophys. Res. Commun. 172:1273-1281.
17. Pohlamn, T. H., K. A. Stanness, P. G. Beatty, H. D. Ochs, and J. M. Harlan. 1986. An endothelial cell surface factor(s) induced in vitro by lipopolysaccharide, interleukin 1, and tumor necrosis factor alpha increases neutrophil adherence by a CDw18-dependent mechanism. J. Immunol. 136:4548-4553.

18. Carveth, H. J., R. E. Shaddy, R. E. Whatley, T. M. MacIntyre, S. M. Prescott, and G. A. Zimmerman. 1992. Regulation of platelet-activating factor (PAF) synthesis and PAF-mediated neutrophil adhesion to endothelial cells activated by thrombin. Semin. Thromb. Hemostasis. 18:126-134.

19. Dicorleto, P. E., and C. A. De La Motte. 1989. Thrombin causes increased monocytic-cell adhesion to endothelial cells through a protein kinase C-dependent pathway. Biochem. J. 264:71-77.

20. Reithmann, C., P. Gierschik, and K. H. Jacobs. 1990. Stimulation and inhibition of adenylate cyclase. Symp. Soc. Exp. Biol. 44:207-224.

21. Nishizuka, Y. 1988. The molecular heterogeneity of protein kinase $C$ and its implications for cellular regulation. Nature (Lond.). 334:661-665.

22. Krebs, E. G. 1989. Role of the cyclic AMP-dependent protein kinase in signal transduction. J. Am. Med. Assoc. 262:1815-1818.

23. Taylor, C. W. 1990. The role of $G$ proteins in transmembrane signalling. Biochem. J. 272:1-13.

24. Collins, S., M. G. Caron, and R. J. Lef kowitz. 1992. From ligand binding to gene expression: new insights into the regulation of G-protein-coupled receptors. Trends Biochem. Sci. 17:37-39.

25. Moss, J., and M. Vaughan. 1988. ADP-rubosylation of guanyl nucleotidebinding regulatory proteins by bacterial toxins. Adv. Enzymol. Relat. Areas Mol. Biol. 61:303-379.

26. Sung, C., A. J. Arleth, B. Storer, and G. Z. Feuerstein. 1991. Modulation of U937 cell adhesion to vascular endothelial cells by cyclic AMP. Life Sci. 49:375-382.

27. Oishi, K., R. L. Raynor, P. A. Charp, and J. F. Kuo. 1988. Regulation of protein kinase $C$ by lysophospholipids. J. Biol. Chem. 263:6865-6871.

28. O'Brian, C. A., N. E. Ward, I. B. Weinstein, A. W. Bull, and L. J. Marnett. 1988. Activation of rat brain protein kinase $\mathrm{C}$ by lipid oxidation products. Biochem. Biophys. Res. Commun. 155:1374-1380.

29. Laychock, S. G. 1989. Coordinate interaction of cyclic nucleotide and phospholipid metabolizing pathways in calcium-dependent cellular responses. Curr. Topics Cell. Regul. 30:203-242.

30. Engelhard, V. H., J. D. Esko, D. R. Storm, and M. Glaser. 1976. Modification of adenylate cyclase activity in LM cells by manipulation of membrane phospholipid composition in vivo. Proc. Natl. Acad. Sci. USA. 73:4482-4486.

31. Gosh, S., and D. Baltimore. 1990. Activation of NFkB by phosphorylation of its inhibitor IkB. Nature (Lond.). 344:678-682.

32. Shirakawa, F., and S. B. Mizel. 1989. In vitro activation and nuclear translocation of NF-kappa B catalyzed by cyclic AMP-dependent protein kinase and protein kinase C. Mol. Cell. Biol. 9:2424-2430.

33. Baeuerle, P. A., and D. Baltimore. 1988. IkB: a specific inhibitor of the NF-kB transcription factor. Science (Wash. DC). 242:540-546.

34. Sparrow, C. P., S. Parthasarathy, and D. Steinberg. 1988. Enzymatic modification of low density lipoprotein by purified lipoxygenase plus phospholipase $A_{2}$ mimics cell-mediated oxidative modification. J. Lipid Res. 29:745-753.

35. Kosugi, K., D. C. Morel, P. E. DiCorleto, and G. M. Chisolm. 1987. Toxicity of oxidized LDL to cultured fibroblasts is selective for $\mathrm{S}$ phase of the cell cycle. J. Cell. Physiol. 130:311-320.

36. Hoff, H., T. E. Whitaker, and J. O'Neil. 1992. Oxidation of LDL leads to particulate aggregation and altered macrophage recognition. J. Biol. Chem. 264:602-609.

37. Steinbrecher, U. P. 1987. Oxidation of human LDL results in derivatization of lysine residues of apolipoprotein $B$ by lipid peroxide decomposition products. J. Biol. Chem. 262:3603-3608.

38. Fogelman, A. M., I. Schechter, J. Seager, M. Hokam, J. S. Child, and P. A. Edwards. 1980. Malondialdehyde alteration of LDL leads to cholesteryl ester accumulation in human monocyte macrophages. Proc. Natl. Acad. Sci. USA. 77:2214-2218.

39. Chomczynski, P., and N. Sacchi. 1987. Single-step method of RNA isolation by acid guanidinium thiocyanate-phenol-chloroform extraction. Anal. Biochem. 162:156-159.

40. Osborn, L., S. Kunkel, and G. J. Nabel. 1989. Tumor necrosis factor alpha and interleukin 1 stimulate the human immunodeficiency virus enhancer by activation of the nuclear factor kappa B. Proc. Natl. Acad. Sci. USA. 86:23362340.

41. Mattila, P. 1991. Protein kinase C subtypes in endothelial cells. FEBS (Fed. Eur. Biochem. Soc.) Lett. 289:86-90.

42. Luscinskas, F. W., A. F. Brock, M. A. Arnaout, and M. A. Gimbrone. 1989. Endothelial-leukocyte adhesion molecule-1-dependent and leukocyte (CD11/CD18)-dependent mechanisms contribute to polymorphonuclear leukocyte adhesion to cytokine-activated human vascular endothelium. J. Immunol. 142:2257-2263.

43. Young, S., P. J. Parker, A. Ullrich, and S. Stabel. 1987. Down-regulation of protein kinase $\mathrm{C}$ is due to an increased rate of degradation. Biochem. $J$. 244:775-779.

44. Bork, R. W., K. L. Svenson, M. Mehrabian, A. J. Lusis, A. M. Fogelman, 
and P. A. Edwards. 1992. Mechanisms controlling competence gene expression in murine fibroblasts stimulated with MM-LDL. Arterioscler. Thromb. 12:800 806.

45. Stelzner, T. J., J. V. Weil, and R. F. O'brien. 1989. Role of cyclic adenosine monophosphate in the induction of endothelial barrier properties. J. Cell. Physiol. 139:157-166.

46. Shimokawa, H., N. A. Flavahan, and P. M. Vanhoutte. 1991. Loss of endothelial pertussis toxin-sensitive $G$ protein function in atherosclerotic porcine coronary arteries. Circulation. 83:652-660.

47. Flavahan, N. A., and P. M. Vanhoutte. 1990. G-protein and endothelia responses. Blood Vessels. 27:218-229.

48. Kume, N., M. I. Cybulsky, and M. A. Gimbrone, Jr. 1992. Lysophosphatidylcholine, a component of atherogenic lipoproteins, induces mononuclear leukocyte adhesion molecules in cultured human and rabbit endothelial cells. $J$. Clin. Invest. 90:1138-1144.

49. Ku, G., A. L. Akeson, M. Mano, C. E. Thomas, and R. L. Jackson. 1991 Products of oxidized linoleate mediate macrophage cytokine release and smooth muscle cell proliferation. Clin. Res. 39:3355-3359.

50. Visvanathan, K. V., and S. Goodbourn. 1989. Double-stranded RNA activates binding of NF-kappa $B$ to an inducible element in the human beta-interferon promoter. EMBO (Eur. Mol. Biol. Organ.) J. 8:1129-1138.

50 a.Rajavashisth, T. B., K. Doan, and J. Mehta. 1993. NF- $\kappa$ B binding cisDNA elements mediate transcriptional activation of M-CSF gene by minimally modified LDL. FASEB (Fed. Am. Soc. Exp. Biol.) J. 7:A341. (Abstr. 1976).

51. Shirakawa, F., M. Chedid, J. Suttles, B. A. Pollok, and S. B. Mizel. 1989
Interleukin 1 and cyclic AMP induce kappa immunoglobulin light-chain expression via activation of an NF-kappa B-like DNA-binding protein. $\mathrm{Mol}$. Cell. Biol. 9:959-964.

52. Collins, T., A. Williams, G. I. Johnston, J. Kim, R. Eddy, T. Shows, M. A. Gimbrone, and M. P. Bevilacqua. 1991. Structure and chromosomal location of the gene for endothelial-leukocyte adhesion molecule 1. J. Biol. Chem. 266:2466-2473.

53. Spengler, R. N., M. L. Spengler, P. Lincoln, D. G. Remick, R. M. Strieter, and S. L. Kunkel. 1989. Dynamics of dibutyryl cyclic AMP- and prostaglandin E2-mediated suppression of lipopolysaccharide-induced tumor necrosis factor alpha gene expression. Infect. Immun. 57:2837-2841.

54. Pober, J. S., M. Slowik, L. Deluco, and A. J. Ritchie. 1992. Elevated cAMP inhibits endothelial expression of ELAM-1 and VCAM-1 but not ICAM1. FASEB (Fed. Am. Soc. Exp. Biol.) J. 6:A1592.

55. Montgomery, K. F., L. Osborn, C. Hession, R. Tizard, D. Goff, C. Vassallo, P. I. Tarr, K. Bomsztyk, R. Lobb, J. M. Harlan, et al. 1991. Activation of endothelial-leukocyte adhesion molecule 1 (ELAM-1) gene transcription. Proc. Natl. Acad. Sci. USA. 88:6523-6527.

56. Berliner, J. A., D. S. Schwartz, M. C. Territo, A. Andalibi, L. Almada, A. J. Lusis, D. Quismorio, Z. T. Fang, and A. M. Fogelman. Induction of chemotactic cytokines by MM-LDL. In Chemotactic Cytokines 4. Springer Verlag, New York. In press.

57. Bevilacqua, M. P., J. S. Pober, D. L. Mendrick, R. S. Cotran, and M. A. Jimbrone. 1987. Identification of an inducible endothelial-leukocyte adhesion molecule. Proc. Natl. Acad. Sci. USA. 84:9238-9242. 